\title{
Speech Act Analysis of Dame Patience Jonathan's Speeches
}

\author{
Bestman Esegbuyiota Odeh \\ Department of Linguistics, Igbo and Other Nigerian Languages, University of Nigeria, Nsukka, Nigeria \\ Augustina Ngozi Eze \\ Department of Linguistics, Igbo and Other Nigerian Languages, University of Nigeria, Nsukka, Nigeria \\ Bridget, O. Dioka \\ Department of Linguistics, Igbo and Other Nigerian Languages, University of Nigeria, Nsukka, Nigeria \\ Chinaza Loveline Ugochukwu \\ Department of Linguistics, Igbo and Other Nigerian Languages, University of Nigeria, Nsukka, Nigeria
}

\begin{abstract}
This research work is centered on the speech act analysis of Dame Patience Jonathan. The main objectives of the work are to identify the types of speech acts in the selected Dame Patience's speeches as well as to discover its effects on the citizens of the country. The theoretical framework adopted for data analysis is Searle's speech act theory. For the analysis, only three speeches of Dame Patience Jonathan will be used. The speeches includes: Chibok girls speech, campaign speeches at Umuahia and Calabar. The study finds out that the speeches could have caused chauvinism and rivalry as well as proving that the then government is inept in solving the problem at hand. The findings also reveal different types of speech acts used by Dame Patience Jonathan using Searle's speech act classification. The work identifies Declarative Speech act, Representative Speech act, Commisive speech acts and Directive speech act. The work also discovers how politicians such as Dame Patience Jonathan used language in such a way to manipulate the listeners/citizens. Furthermore, the work discusses the effect of Dame Patience Jonathan's speeches on the people and how the people/citizens reacted to the speeches. The study recommended that if political figure wants to make a speech or address the citizens, s/he should weigh the speech and its consequence.
\end{abstract}

Index Terms - speech act, Chibok girls, political discourse, election

\section{INTRODUCTION}

Nigeria, as at the tenure of President Goodluck Jonathan, was faced with terrorism, kidnapping, high rate of mortality etc. The country was in chaos as several states were attacked by Boko Haram and other terrorists' groups. Several government spokespersons tried in their words to address the citizens on the ways the issues are being handled. This paper therefore seeks to analyze some selected speeches of Dame Patience Jonathan, the wife of the Former President of the Federal Republic of Nigeria, since she was one of the important figures that tried in her own way to proffer solution to the situation. In Nigeria federal system of government, the status of the first lady of Nigeria is an informal but accepted office held by the wife of The President of the Federal Republic of Nigeria. The world is characterized by conflicting ideological stances. Many people are still vulnerable to the oratorical prowess of politicians and are influenced easily by ideologies that are imagined in the speeches of political actors. Irrespective of these scholarly researches, no speech act research has been done in the area of analyzing the speeches of Dame Patience Jonathan. The ability to use language to persuade or manipulate is more prominent in the lives and activities of politicians.

Dame Patience Jonathan is the wife of Goodluck Jonathan, the Former President of the Federal Republic of Nigeria. Before her position as the first lady of Nigeria, she had been in the educational sector where she taught for some time before she was transferred to the Ministry of Education where she worked before her husband became the Deputy Governor of the state in the year1999. She however became the first lady of Bayelsa state from 2005 to 2007 when her husband became the Governor. Again, her husband became the vice president of Nigeria and subsequently the president which elevated her status. However, this made her the first lady of the Federal Republic of Nigeria.

Given the enormous domestic and global significance of the said speeches in times of national political turmoil (insecurity, insurgency, and bad state of economy) in Nigeria, it is crucial to decipher ideological traits typical of Dame Patience embedded in her speeches. In other words, this research work tends to examine how far her speeches saved the situation of the country at that time as well as the effects they had on the people. The interest of this work lies on how Dame Patience Jonathan used words in her speech. The study is set to examine and find out whether her speeches were able to help her in the political battles during her husband's regime, either by persuading his audience or masses with her adequate use of language. The specific objectives are to identify the speech act types that manifest in the selected 
speech, assess the manner in which the speeches of Dame Patience Jonathan portray her manipulative intent and to analyse the effect of her speeches on the audience.

\section{LITERATURE REVIEW}

Quite a vast number of researchers have carried out researches on speech especially political speeches which show similarities with the one under study.

A prominent contribution on speech analysis was the research conducted by Omozuwa and Ezejideaku (2009) on the stylistic analysis of the language of political campaigns in Nigeria. Here, the authors set out to unravel the significance of the aesthetic use of language in campaign speech. They observe that political campaign language is characterized by propaganda through attack on party, exaggeration, vagueness and diatribes. Furthermore, the language of campaigns is characterized by pidgin, coinages, allusion, promises, literary language, repetitions and they are rhetorics in figurative term.

In the study conducted by Agbedo (2011) on "fuel subsidy removal and mind game in Nigerian: a critical discourse analysis perspective", he critically examines how the Nigerian government employs the role of language to influence the opinions and views of the generality of the Nigerians. The research employed the theoretical and methodological aspect of Critical Discourse Analysis. The government use language in order to make the citizens support their moves intended towards the removal of the subsidy which will invariably results in an increase in the price of petroleum products. He observed that dominant groups in our contemporary society use all shades and hues of language to create coercive tactics, persuasion and or interpersonal and group base influence, manipulation to control public discourse and run unpopular policies down the throat of the silent majority or populace equally appropriates the vocative power of discourse and accesses to the media to resist the systemic class domination and oppression.

Taking a glance in the study conducted by Ahamefula and Okoye (2012) entitled felicity or insincerity: The pragmatics of selected speeches of Nigeria public leaders"; they looked at the use of language by the then president of Nigeria, chief Olusegun Obasanjo and pointed out on their study that the then president violates the basic tenets of the Gricean cooperative principle and Austin's felicity conditions which all propagate the need for good communication between and among people and groups of people. Thus, they pointed the following expressions in the president's word which they observed from their finding to buttress their point: "this idiot, go get a job" _ a statement he used against the media chiefs to express his frustration towards their attempts to analyze and broadcast his words and actions as the president; "shut up"- his outburst to the victims of the Ikeja Military Cantonment Bomb blast when they cried out to him.

Alo (2012) examines the political speeches of well known African leaders with a look of viewing how politicians beg the Africans on the expediency of different political and socio-economic policies and plans to facilitate African economic recovery and development. The study also looked at a rhetorical analysis of selected political speeches of famous African leaders where it gathered that the speeches of African leaders are preoccupied with the political and socioeconomic problems of the continent and the need for change. .The study revealed four dominant ideological preoccupations which are: national unity, nationalism, globalism and self -reliance.

Waya and Nneji (2013) in their work adopted the Speech Act Theory of Austin (1962) and Searle (1969) in the analysis of the speech corpus. Using the Overall Relative Frequency Percentage (ORFP) as a methodological technique, the study discovers that Jonathan made use of assertive acts than other speech acts. The study revealed that the sentences that were vindictive and directive made way for him to assert authority and exercise constitutional power as the president. The study concluded that good governance becomes visible and possible if the leaders work in line with their beautiful promises. Therefore, the paper seeks to fill a major gap by examining the ideological component of change adopted by Dame Patience Jonathan in her abduction of Chibok girls, campaign speeches and people democratic party (PDP) women presidential rally.

Aboh (2016) studied Jega speeches during the 2015 Nigeria general election. The main purposes of the work are to identify the extent at which Jega's speeches reflect the values of INEC and the outcomes of Jega's electoral speeches. The researcher adopted cooperative principle and critical discourse analysis for analysis of data. For the analysis of Jega's two speeches, he adopted the descriptive method. Having used the maxims of cooperative principle, the researcher observed that the whole sections fulfilled the maxim of quantity. He added that the speech A fulfilled the maxim of quality but speech B flouted the maxim, thus committing a conversational implicature. The researcher also noted that Jega's speeches reflected the values of INEC. The values include: autonomy, integrity, credibility, equity, impartiality, dedication, excellence, transparency and teamwork. The study also stated that the informative power of Jega's speeches is very strong as it lured people to act positively towards the information. The study recommended that anyone preparing for a speech should do that meticulously in order to ensure a value-added speech. Also, other researchers should endeavor to study the speeches of various stakeholders who are not really politicians.

In the same vein, Chukwu (2016) looked into President Muhammadu Buhari's language use using Critical Discourse Analysis as its framework. The speeches for this work were gotten via internet and newspaper and are selected using purposive sampling method. The study provided insights to the strategies adopted by Muhammadu Buhari in his speeches. These include: deployment of pronoun, propaganda and presentation of topical issues, etc. The study exposed the fact Buhari made use of adequate pronouns in uniting and aligning himself with the electorates and masses. The 
study also reveals his use of propaganda which served as a linguistic tool for the defamation of rival's character and upliftment of personal image. Conclusively, the study noted that Buhari's language use is aimed at diverse purposes ranging from his aim to manipulate the mindset of the electorates so as to get their trust and his desire to impress the masses and foreign representatives.

Nwoye (2017) evaluated selected media interviews of Government spokesperson and the citizens of Nigeria. The study investigates the discursive strategies employed by the government and Nigerian citizens on some crucial national issues in order to reveal power and dominance. The study sampled twenty media interviews from which forty-seven were utterances extracted and analyzed. The research revealed that both the government and citizens used these pro-forms: 'we', 'I', 'our', 'you' and 'me' respectively. The study stated that it is within solidarity that their pronouns were used to establish oneness and attraction of public sympathy. The government used some of the pro-forms to represent the government as an entity that is inclusive in their discharge of duty, while the citizen used the pro-forms to attract sympathy, challenge and encourage the government. Framing as a strategy is employed by both sides of the discourse as pointed out by the researcher. On the side of the government, framing accounts for the ways government spokesperson apportion blames on the past government. On the part of the citizens, blames are shifted to the government and the President respectively.

From the reviews thus far, it can be seen that none of the researchers have carried any research on the Speech Act Analysis of Dame Patience Jonathan. The reviews show that political speeches have several effects on the citizens. Most speeches are employed by government for ulterior motives. The research tends to fill the gaps seen from the previous studies.

\section{THEORETICAL FRAMEWORK}

\section{Speech act theory}

Speech act theory is a crucial aspect of pragmatics. It is based on how a speaker understands an utterance. This theory was put forward firstly by Austin in 1962 in his work entitled "how to do things with words". Austin (1962) notes that one thing many utterances do is to make propositions. Propositions are presented basically in form of statements, questions or other grammatical forms. These utterances are linked with happenings in a world possible. Searle (1969) further threw more lights on the theory.

Speech act is seen as the actions performed in saying something (Austin, 1962). The utterances are classified into two: constatives and performatives. Constatives are seen as utterances that can be evaluated along a dimension of truth. According to Morris (2007), Austin began not by focusing on sentences which seem to belong grammatically to that type but which look odd in a more unsettling way. These sentences which Austin called performatives, seem not to describe anything in the world at all, and so seem not to be true or false. Instead, Morris notes further that they seem to get something done. In using performative utterance, a person is not just saying something but is actually doing something at the same time if certain real world conditions are met. In the world of speech acts, attention has been shifted to realizing an utterance in a speech act situation rather than on sentence construction. (cf. Wardhaugh, 2006). Austin noted clearly the contrast between constative utterances and performative utterances. Performative utterances consist of performative verbs which spell out clearly the illocutionary forces of the sentences. Examples of such verbs are: acquit, abolish, accept, admonish, advise, affirm, announce, apologise, ask, assent, authorize, beg, query, promise, order, recommend, resign, swear, reject, christen, sanction, and prescribe (cf. Agbedo, 2015). Osasinwo (2003) notes that constatives are verbs that are used to make statements, describing situations, events, state of affairs, observing phenomena and asserting their truth or otherwise. These constative verbs are grouped as descriptive, ascripitve, retractive, assentive, disputative, responsive and suggestive.

Austin further distinguished actions performed when an utterance is being produced in three segments: locutionary (the act of saying something, illocutionary (what one does in saying it) and perlocutionary (what one does by saying it). Searle (1976) grouped speech acts into five categories. They are: assertive, directive, comissive, expressive, effective, verdictive and quotation. Following Agbedo (2015) idea, assertive acts employed phrases to form in the addressee's specific idea, proposition or belief. With assertive, the speaker commits himself to something being true. The directive acts beckon on the speaker to act, but do not require the sender to return any action of his own. Commissive act has to do with committing oneself to future action. Expressive act has to do with expression of feelings or emotion to the receiver. It involves one's psychological state of reasoning while declarative speech act is grouped into effective and verdictive speech act (cf. Clark, 1996). The effective and verdictive speech acts according to Clark are the same but with slight difference. The effective and verdictive acts require the sender to be in power in an institution. The difference lies in the fact that effective speech acts are those utterances that are able to change institutional state of affairs while verdictive acts refer to judgments made by persons vested with specific institutional power.

Searle (1969) approached speech act analysis from a different light. He identified two types of speech act as: direct and indirect speech. In addition to this, Searle (1976) also classified speech act theory into the following large-scale classes:

1. Declaration: by declaration, we mean words and expression that change the world by their utterance. The utterance one gives is what brings changes to the world. For examples; I bet, I pronounce, I declare, I baptize 
etc. I Baptise this boy, John Okafor which changes a baby that has no name to one with a name. Another example: I pronounce you husband and wife who changes the status of the people from single to married.

2. Representatives: they are what speakers are convinced to be the state of things. Examples include: hypothesizing, describing, predicting, claiming etc.

3. Commisives: These are acts in which the words are meant for the addressee to carry out an action. In other words, it commits the speaker to take some futuristic action.

Examples include: 'volunteering', inviting' 'guaranteeing', 'swearing', 'offering', 'promising', 'agreeing' etc.

4. Directives: this class contains acts in which the words are meant to make the addressee carry out an action. Examples are requesting, suggesting, inviting, commanding, forbidding etc.

5. Expressives: this class has to do with the speaker's feeling. This refers to expression of some psychological state. Examples are; 'deploring', 'praising', regretting' apologizing' and 'congratulating'.

From the discussion above, it is seen that there are different types of speech acts as proposed by Austin (1962) and Searle (1976). For this work, Searle (1976) classification of speech act will be used for analysis of data.

\section{DATA PRESENTATION AND ANALYSis}

The data for analysis are three speeches of Dame Patience Jonathan (henceforth, DPJ), which are: the speech in reaction to the abduction of the Chibok girls (henceforth referred to as 'Speech A'), campaign speech at Umuahia (Speech B), and campaign speech at Calabar (Speech C). These speeches will be analysed using Searle's Speech Acts Theory.

\section{A. Types of Speech Acts in Dame Patience's Speeches}

In this part of analysis, the speech acts types that manifest in the speeches under study will be categorised and analysed.

\section{Declarative speech acts}

Declarative speech acts are those utterances or expressions that change the world by their utterance. This type of speech act can be referred to as assertives. In Speech A, DPJ made a declarative speech act when she said:

There is God o! There is God o! The bloods we are sharing, there is God o!

From the above excerpt, the statement, 'There is God o' asserts or declares the existence of a Being, who oversees the actions of human beings. This assertive statement draws the attention of the perpetrators of violence, especially the Boko Haram sect that kidnapped the Chibok girls that there is a God who will judge them in the 'bloods' they are 'sharing.' In the same speech, the statement contains element of assertiveness or declaration:

Do you come with two teachers? You were not informed, too? Eh? Kontinu (Continue). No Problem.

From the utterance above, after the interrogative constructions, DPJ ended with a declarative statement, 'Kontinu. No problem.' This declaration establishes her stance on the matter, which enables readers and the audience to ascertain the position of DPJ on the matter.

More so, in speech B, DPJ referred to her husband, Goodluck Jonathan, as 'talk na do', which means that her husband is a man of his words. She went further to expatiate her utterance by saying, 'He does whatever he says.' These declarative speech acts substantiate the character of the person being referred to i.e. Goodluck Jonathan. Evident in these speech acts is the knowledge the speaker knows, to an extent the person referred to and believes in what he can do. Instances can be drawn from the campaign speeches in Umuahia:

“Our Los Angelos is here, our L.A is here, our boys can do it, our women can do it, we don't need L.A, we don't need Los Angelos".

Here, the statement shows that DPJ knows what the husband, Goodluck Jonathan has achieved during his tenure.

\section{Representative speech acts}

Representative speech acts commit the speaker to what he/she said. In Speech A, an instance of a representative speech act is, "God will see us." In this speech act, DPJ commits herself in the discourse. The personal pronoun 'us' used in the utterance is an in-group or inclusive one. This then means that God sees us in all that we do. Indirectly, the implication of the statement is that even in her public and private dealings, God sees her. With this interpretation, she also commits herself to what she said. However, she accepts the fact that God sees everybody and no one is exempted even her.

In Speech B, another utterance that contains elements of a representative speech act is:

If we have not done well, come out and challenge me.

A closer look at the above excerpt suggests that DPJ sees herself and her husband as people who are open to criticism and ready to answer to their actions. This statement commits her in the sense that she has opened the doorway of criticisms both constructive and destructive. However, this implies that if in the nearest future, the masses begin to question the government of she and her husband, no one will stop them (the masses) or speak ill of them because DPJ has surrendered herself for criticisms and challenge.

In Speech B as well, DPJ made another representative speech act when she said:

If my husband decides to come back after eight years again, I will drag him inside the house and tell him to allow the younger ones to rule. 
From the above, representative speech act commits DPJ to what she has said. This commitment requires her to keep to her promise if all conditions are met. These conditions are if they win the 2015 presidential election and complete eight years in office. Because these conditions were not met due to the fact that Goodluck Jonathan lost in the presidential race, the execution of the speech acts was not obtainable. In addition, representative speech act entails that the speaker must fulfill the commitment he/she has made to the audience.

\section{Commisive speech acts}

Commisive speech act commits speakers to some future actions like offering, promising, or swearing. An instance of commisives was found in Speech A.

Now the first lady is calling you: come I want to help you. Come to find your child missing child...

The above statement is commisive in nature because of its promising content. In this statement, DPJ is committing herself to help parents find their missing children. This implies that the then government is doing everything within their strength to save the missing children. Be it as it may, one striking thing embedded in her speech act is a promise.

In Speech B, DPJ made the following statements:

I vow to do more, I vow to do more, we are going to do more. If you vote for Goodluck come March 28, 2015, he will do more. My husband, the President of Nigeria, is 'talk na do'. He does whatever he says.

DPJ in the above assertions promises the electorates on behalf of her husband that he will do more than he has done in the previous years as the President. In the same vein, she offers a better Nigeria if her husband is re-elected into power.

In addition, in Speech C, DPJ made another statement that has commisive speech act:

...Baby wait let me go and vote baby wait let me Exercise my

Mandate, Baby wait let me go and do what I will use to feed

you. You won't die, let me go and vote, after voting, I will

come and deliver you, and you won't die because Goodluck has

given all the safety measures, you won't die.

This statement was made in Calabar referring to pregnant women who would want to be delivered of their baby before voting. DPJ addressed them by telling them they will not die even if they leave the hospital where they should be going for childbirth and come to polling unit. The reason behind this is the ideology that Goodluck has given all the safety measures. This statement made the speech act a commisive one because of the promise it contains. After criticising the opposition, she offered continuity in the following words,

"From old age nothing, so nothing like change. Rather (it) is continuity."

This then implies that she and her husband will continue in their bid of transforming Nigeria for good.

4. Directive speech acts

This category covers act in which the words are meant at making the hearer do something, such as commanding, requesting, inviting, forbidding or suggesting. In Speech A, DPJ said:

Now the First Lady is calling you. Come, I want to help you. Come to find ya [your] be... ya [your] child, ya [your] missing child. Will you keep quiet? Chai! Chai!

The above statement is a directive one because she is inviting the parents of the missing girls to come to her so that they will brainstorm on how to rescue the kidnapped girls. In 'Will you keep quiet?' suggests to the mothers what they should not do, which is not to keep quiet but to do something to address their situation. In addition, her statement that 'she will drag her husband inside the house if he wants to come back after eight years', is a directive speech acts in the sense that she forbids her husband of not giving the youths the chance to rule the country. Also, in Speech B, the statement, "If we have not done well, come out and challenge" is a directive speech acts because through it, DPJ invites the masses to come and conduct a check and balance on her and the husband.

Admittedly, in Speech C, DPJ made the following directive speech acts:

Anybody that comes and tell you change, stone that person. Anybody that comes and tell you he will change, stone that person.

Even though belle (pregnancy) is disturbing you, tell it baby, baby let me go and vote. Baby wait let me go and exercise my mandate.

In the first excerpt, DPJ commands, suggests or directs her audience on what they are going to do in a scenario when someone approaches them with a change mantra, which is to stone the person. In the second one, she suggests that a woman due for delivery should choose her franchise over childbirth because according to her, her husband has taken care of everything. As such, she will not have any complications or die in the process of childbirth after exercising her franchise.

5. Expressive speech acts

This last type of speech act includes words that state the way the speaker feels such as apologising, praising, congratulating, deploring, and regretting. In Speech A, an instance of expressive is seen in the statement of DPJ where she says:

There is God. There is God in everything we are doing. Those bloods that are sharing in Bronu [Bornu] will answer. 
The above statement has a deploring content because it condemns and expresses strong disapproval of the kidnapping of the Chibok girls. In this statement, DPJ expresses her mind and her position in the situation at hand. She expresses that Boko Haram who masterminded the kidnapping should know that there is God who sees their bad conduct. More so, she expresses that the blood of those killed will one-day torment them.

From the above analysis, DPJ made use of three speech acts each for declarative, and representative. On the other hand, DPJ made four commisive speech acts and four directive speech acts. Only one expressive speech acts was identified in the analysis. The number of these speech acts has its implication. The number of expressive speech acts is one because DPJ never wanted disclose herself openly so that her words will not be used against her. Her ideologies are what she revealed through declarative and representative speech acts. Commisives and directives are four each, thus recording the highest numbers, because DPJ believed that these speech acts will go a long way in making her and husband to emerge victorious in the presidential election. These speech acts have their manipulative intent and the exegesis of these speech acts is the major preoccupation of the next section in this work.

\section{B. The Manner in Which the Speeches of Dame Patience Jonathan Portray Her Manipulative Intent}

Another aspect of speech acts theory is illocutionary force, which is what the speaker does with his word, the role of the words, the specific idea that the speaker has in mind. During electioneering period, politicians or campaigners use many forms of manipulative words to make the hearers do their bidding.

In Speech A, the repetitive use of 'There is God o' for eight times is manipulative. DPJ uses it to drive her message home and emphasizes on what she wants to communicate. This repetitive way of using language sends a message to the audience that DPJ is concerned about what has happened, which is the kidnapping of Chibok girls. In effect, if people had wanted to accuse her of being indifferent or not being a caring mother, with this, she has exonerated herself.

Continuing, inviting the mothers of the kidnapped girls in the following words, "Now the First Lady is calling you' creates in the mind of the intended audience that she is concerned about their well being. The use of 'First Lady' did not come accidentally. The phrase, 'First Lady' was used in expectancy that the people being invited would know that it is not an ordinary person that is calling them but the wife of the President. It also creates the notion that a 'First Lady' can be of a good use in Nigeria opposed to those who aim at scrapping the office of the First Lady. Admittedly, in order to complete her manipulative intents, she shed tears in front of Nigerians, which passed a message of grief, motherly care, and the commitment of Goodluck led administration in rescuing the kidnapped Chibok girls. This combination of verbal and nonverbal modes of communication made Nigerians not to criticise the Government the way they have planned. In fact, the speech resulted in an 'accidental humour' because Nigerians left the issue at hand and started discussing the First Lady's speech and making a joke of her statements, "Nah only you waka come?' 'The bloods we are sharing" ...etc. This gave her time to think of what next to do.

In Speech B, the utterances of DPJ have its manipulative contents. In the statement, "If we have not done well, come out and challenge me," it sends the message of self-confidence. The implication of the statement is that she and her husband have done well to the extent that the criticisms or challenge they will face is seemingly negligible. When someone invites another to challenge him/her, the speaker is confident that the hearer will not have much to say. The manipulative intent, therefore, embedded in the above utterance is meant to create an impression in the minds of the hearers that Goodluck led administration has performed well. It also connotes that they (Goodluck and DPJ) that practice democracy in the sense that they entertain the opinions and criticisms of the masses. But one may begin to wonder why DPJ started with a plural pronoun 'they' and ends with a singular pronoun 'me.' A closer look at it tends to suggest that she makes all decisions so she is responsible for all of them. This might be a scenario where the axiom that men are the head but women are the neck that turns the head becomes appropriate.

Put differently, it may mean that Goodluck is not a domineering or secretive husband in the sense that he does not hide anything from the wife. This might be the rationale behind DPJ offering herself to be challenged because she is been carried along in all political decisions and activities. In the same speech, DPJ said that she will not allow her husband to come back after eight years because the younger ones should be given the chance to rule. There are two implications of this statement that showcase her manipulative intent. Firstly, she is throwing jibes at All Progressive Congress' (APC) flag bearer, Muhammadu Buhari who was seventy years in 2015, to exit the presidential race and leave it for younger ones. This is expected to pass a message to the electorates that they should not vote for an old man during the election because his brain is backward. Secondly, DPJ through her statement wishes to draw the support of the youths to vote for her husband because she will make sure that they are given the opportunity to rule after four years. If the illocutionary force of this statement yields the desired effects, the youths will be left with no option than to vote for someone who acknowledges their existence and the role they play in governance. In essence, making promises is one of the ways DPJ manipulates her audience. Promises increase their hopes and trust. This act of promising can as well be found in the statement, "If you vote for Goodluck come March 28, 2015, he will do more." For her, Goodluck has done greater things than his predecessor and if Nigerians want to continue to enjoy the good governance offered them by Goodluck and need more, they should vote for Goodluck in the coming election.

Furthermore, DPJ was out to convince Nigerians to hate APC with passion. Through hate speech and derogatory words, DPJ emphasised APC's shortcomings and PDP's successes. When DPJ said that 'people should stone anybody that comes with change (referring to APC because of their change mantra),' she manipulated the audience in such a way that they will not see anything good that comes from APC. As such, no one will be eager to vote for someone he/she 
stoned during the electioneering period. DPJ further explained that Buhari did not achieve anything in his youth and hence nothing can be achieved in old age. This is evident in the excerpt below:

What you did not do in Kirikiri, is now that old age has caught up with you, you want to come and change? You can't change, rather you will turn back to a baby. You will turn back to a baby. From old age nothing, so nothing like change.

From here, the person being referred to is Buhari who according to DPJ did not achieve anything when he was the Military Head of State at a very young age. By implication, Buhari cannot achieve anything now that he is old. By digging up history, DPJ tried to manipulate the electorates by making them know that what Buhari could not achieve at a youthful age will be difficult to be achieved in old age. Indirectly, since her husband is younger than Buhari, DPJ invites all to vote for a fresh blood instead of an old man.

Finally, the statement, “Goodluck has given all the safety measures. You won't die," has a manipulative intent in the sense that it promises the pregnant women that no harm will befall them if they go to the polling stations to vote because the president has put everything in proper shape. If there were to be any pregnant woman who was afraid of voting because of the violence that takes place in polling stations, her fears will be subsided because a promise has been made to her.

\section{Effects of Dame Patience Jonathan Speeches on the Citizens}

This section focuses on the effects of the speeches studied above on the citizens. In other words, it centers on discovering if the speeches achieved the aims to which it is said. To study this, reactions of the citizens which will be gotten in form of comments will be analysed for each speech.

1. Speech A

From the analysis above, it is pertinent to note that speech $\mathrm{A}$ is meant to show that the then government is aware of the people's predicament and are trying so hard to make things better for them. Put in other words, the problem of the citizen is also the problem of the government. The speech is meant to calm the aggrieved citizens and to show that the then President; Goodluck Jonathan is not silent about the terrorist and their destructive deeds. DPJ also cried during this speech presentation in order to get pitied from the citizens. The question is, did the citizen get the message?

From the comments on the speeches, the citizens seem to be annoyed because the speech of Dame Patience Jonathan and the public outburst did not in any way bring back the abducted girls. In one of the reactions gotten from saharareporters.com titled "open letter first lady Dame Patience", the writer notes:

Madame Patience, let your husband and his advisors handle business. Given the lack of constitutional powers you have to handle such affairs of grave national security and international security, perhaps, you best leave it to those whose duties are to act (saharareporter.com).

The abduction incident is one that needed urgent action and not gathering parents and teachers to weep and only talk. Also, due to the lack of action from the government at that time, the writer opines that it shows: "lack of political will, ineptness, and lack of strategy and security intelligence from the government of Nigeria against Boko Haram". To Patience, she writes:

Let your husband as the president show decisive action. If he wants to contest for elections next year (not like you've made any secret that he wants), let him prove his mantle by leaving the politicking to the side and show that this shadowy extremist group will not bring Nigeria to its knees (net.ng).

The writer's suggestion shows that at the point of the first lady's speech, the president has been discreet about the incident as if he was unconcerned. In such case, the citizens are expecting him to address them and also to take action.

Another report from the net.ng notes that:

Patience Jonathan's reaction was stunningly callous; according to state news media, she told one of the protest leaders, 'you are playing games. Don't use school children and women for demonstrations again (net.ng)

To be callous means not feeling or showing any concern about the problem or suffering of other people. Dame Patience told a citizen protesting not to play games. The question is: how can aggrieved citizens protesting play games? The statement though said to be callous has another implied meaning. They are told to stop demonstrating in order to stop publicity and also to stop painting the government black. In these responses so far, the speech of Dame Patience did not achieve its aim despite the public outburst. From the reactions, the incident of Chibok girls' abduction and the subsequent reaction from the government also made the then president, Goodluck Jonathan to lose the election.

\section{Speech $B$ and $C$}

The reaction of these speeches can be analysed together since they all deal with campaign. The campaign speeches made by DPJ are actually for then President running for the next presidential election. The aim of these speeches was to solicit for votes from the citizens. From the comments online, her speech in Calabar:

"were in bad taste and capable of inciting violence and ethnic division among the people ahead of the elections" (vanguardngr.com).

It was also reported that:

Instead of the First Lady to use her position to campaign on the issues in the elections, she had by comments preached violence and resorted to character assassination (vanguardngr.com).

In Dame Patience campaign speeches, she slandered the name of the incumbent president's opposition, Muhammed Buhari. She referred to him as 'brain dead'; in another situation Muhammed Buhari and the All progressive congress 
(APC) stakeholders and supporters were referred to as 'conductors' since conductors are the only ones that ask for change. The implication of DPJ's hate campaigns is that PDP and its supporters seems agitated and desperate since they did not reprimand the First Lady for such hate speeches but instead protected her. Also, the campaign speeches created ethnic bigotry as seen in the comment:

Why this kind of deliberate preaching of ethnic chauvinism, playing up the ethnic card? Now, what will our brothers and sisters in the North think about us from the South West and indeed the entire South? It is unthinkable but this is the reality of our circumstance as the First Lady went gaga, uttering provocative pronouncements with reckless abandon (vanguard.com).

Now, this is exactly what the campaign speeches resulted to. It pitched the North against the South and vice versa. Also, after the speeches, the two parties, All Progressive Congress (APC) and People's Democratic Party (PDP) seemed to be at logger heads, trying to publicly disgrace and insult each other. This could be seen in the lampoon created by APC members to make jest of DPJ. APC reported DPJ to different governmental and non-governmental bodies, though she was protected by PDP. In the end, the husband and the incumbent president, Goodluck Ebele Jonathan loses the election in which case the aim of the speech was not achieved. In other words, it achieved a negative effect on the citizen.

\section{CONCLUSION}

The research focuses on the speeches of Dame Patience Jonathan. The speeches analysed for this study are: The Chibok girls' speech, her campaign speech at Umuahia and another campaign speech at Calabar. The speeches were analysed using Searle's Speech act analysis. With the use of this theory, the research work finds out the types of speech act that existed in Dame Patience Jonathan's speeches. These include: declarative speech act, representative speech act, commisive speech act, directive speech act, and expressive speech act. In declarative speech act, there are utterances that established DPJ's stance on certain matter and also her knowledge about a particular issue. Representative speech act shows utterances that commit the speaker to what she has said while commisive speech act are utterances that commits speakers to some future action. Directive speech act on the other hand, includes words that are aimed at making the hearer do something while expressive speech acts are utterances that state the way the speaker feels.

Also, there are evidences of illocutionary force aimed at manipulating the audience. In the Chibok girls' speech, DPJ tries to manipulate the citizen to believe certain ideas which she passes across. For instance, the aim of shouting 'there is God oo' severally is in her bid to make herself and the then government free from the accusations that piled up against them. In other words, it is a tactic to exonerate her from blames. Her campaign speeches also bear evidences of manipulative intent, when she said that she would not allow her husband to come out after eight years and that the youths will be given a chance to rule; the idea was to manipulate the youths to vote for a candidate that have their course in mind. The hate speech and derogatory terms she employed is manipulative since it instigates the idea that nothing good will emanate from the opposing party being All Progressive Congress (APC), if voted into power. Also, DPJ dug up an issue that happened in history in order to prove that the people's democratic party (PDP) flagbearer; Mohammed Buhari cannot achieve anything given his age.

On the effects of the speeches on the citizen, the speeches did not achieve its aim and as such the reaction of people seem to be negative. From the comments online, the Chibok girls' speech was said to be callous. Despite the outburst, people still felt that the incumbent government is not working. For the campaign speeches, the flagbearer, Goodluck Ebele Jonathan being campaigned for did not win. This could be as a result of the insult and ethnic chauvinism that come with the speech.

The research work also identified the grammatical blunders committed by Dame Patience Jonathan. In all the speeches analysed, there are evidences of incorrect use of English language. This implies that Dame Patience Jonathan is not proficient in the use of English. This in a way affected the content of the speeches. It was also observed that if the citizens adhered to the instructions of the speeches of Dame Patience Jonathan, the country would have been in chaos. So, if any political figure wants to make a speech or address the citizens, s/he should be weighing the speech and its consequences.

\section{REFERENCES}

[1] Aboh, S.C. (2016). A sociolinguistic study of Jega's speeches during the 2015 Nigeria's General Election. A B.A project, department of linguistics, University of Nigeria, Nsukka.

[2] Agbedo, C.U. (2008). A speech act analysis of political discourse in the Nigeria print media. Ikenga International Journal of African studies, 10 (1\&2), 159-191.

[3] Agbedo, C. U. (2011). Fuel subsidy removal and the mind control game in Nigeria: A critical discourse analysis perspective. Paper presented at the $24^{\text {th }}$ annual conference of the linguistics association of Nigeria (LAN) at Bayero University Kano. $5^{\text {th }}-9^{\text {th }}$ Dec. Retrieved on May, 12, 2018. http://linguisticsafrikana.com.

[4] Agbedo, C.U. (2015). General linguistics: historical and contemporary perspectives. Nsukka: ACE Resource Konzult.

[5] Ahamefula, N.O. \& Okoye. (2012). Felicity and insincerity: the pragmatics of selected speeches of Nigerian public leaders. In A. B. C. Chiegboka, T. C. Utoh-Ezeajugh, E. U. Ibekwe, C.C. Nwosu, N. C. Oguno, \& K. L. Nwadialor (Eds.). The Humanities and Good Governance, (707-712). Nimo: Rex Charles and Patrick Ltd. 
[6] Alo, M. A. (2012). A rhetorical analysis of selected political speeches of prominent African leaders. British journal of arts and social sciences, 10 (1), 45-57.

[7] Austin, J. L. (1962). How to do with words. London: Clarendon press.

[8] Canpaign Speech at Calabar. Retrieved from Https://www.youtube/G0wKr44RJYY.Accessed on 08/08/2018.

[9] Campaign Speech at Umuahia. Retrieved from Https://www.youtube.com/Watch?v=D4s2zsy_CWQ\&t=94s. Accessed on 08/08/2018.

[10] Chukwu, L. E. (2016). President Muhammadu Buhari's Language use: A critical discourse analysis. A B.A project, department of linguistics, University of Nigeria, Nsukka.

[11] Clark, H. H. (1996). Using language. Cambridge: Cambridge University Press.

[12] First lady by her comments preached violence. Retrieved from https://www.Vanguardngr.com. Accessed on 08/08/2018.

[13] Missing chibok girls. Retrieved from Http:www.youtube.com/watch?v=oMwIKuoAj0. Accessed on 08/08/2018.

[14] Morris, M. (2007). An introduction to the philosophy of language. Cambridge: Cambridge University Press.

[15] New York Times slams Goodluck jonathan and patience reactions to \#BringBackOurGirls. Retrieved from http:www.thenet.ng.com. Accessed On 7/08/2018.

[16] Nwoye, D. M. (2017). A critical discourse analysis of selected media interviews of Government Spokesperson and the citizens of Nigeria. A B. A project, Department of Linguistics, University of Nigeria, Nsukka.

[17] Omozuwa, V. E. \& Ezeojideaku, E. U. C. (2009). A stylistic analysis of the language of political campaigns in Nigeria: Evidence from the 2007 general elections. African Journals Online, 6, 40-42.

[18] Open Letter to First lady Dame patience. Retrieved from Http://wwwsaharareporters.com. Accessed on 7/08/2018.

[19] Osasinwo, W. (2003). Introduction to discourse analysis and pragmatics. Lagos: Femolus-Fetop Publishers.

[20] Searle, J. (1969). Speech acts. Cambridge: Cambridge University Press.

[21] Searle, J. (1976). Indirect speech. In P. Cole and J. Morgan (Eds). Syntax and Semantics, 3, 59-82.

[22] Wardhaugh, R. (2006). An introduction to sociolinguistics $\left(5^{\text {th }}\right.$ ed.). Oxford: Blackwell Publishers.

[23] Waya, D. \&Nneji, O. (2013). Pragmatic analysis of victory and inaugural speeches of president Jonathan. A measure for transformation and good governance in Nigeria. Innovare Journal of Social Sciences. 1, (2), 17-21.

Bestman E. Odeh hails from Delta state and was born on $7^{\text {th }}$ June. He is a scholar who is interested in academic excellence. He got his B. A (Linguistics) and M.A (Linguistics) at the University of Nigeria, Nsukka. He has published articles which include: slang expressions used amongst students in Warri Metroplis, Nominalisation of Igbo personal names, lexical ambiguity in Urhobo, an $\mathrm{X}$-bar analysis of aspect in Yoruba' in Ideal journal of Igbo studies, 12(2), 164-183 etc. His area of specialization is morphology and syntax.

He is a member of the Igboscholars' forum, Nigeria and also a member of Linguistics Association of Nigeria (LAN) and presently a PhD student in the department of Linguistics, Igbo and Other Nigerian languages, University of Nigeria, Nsukka.

Augustina N. Eze has B.A, M.A and PhD in linguistics from the University of Nigeria, Nsukka. She also has PGDE from the same University. Augustina specializes in sociolinguistics. She has published 'an X-bar analysis of aspect in Yoruba' in Ideal journal of Igbo studies, 12(2), 164-183. She is a member of Linguistic association of Nigeria and Igboscholars' forum, Nigeria.

Bridget Ogechi Dioka was born in Mbaise, Imo state on the $2^{\text {nd }}$ of February. She has a bachelor of Arts Degree and a masters of Arts Degree in Linguistics and Igbo language at the University of Lagos, Akoka. She specializes in Semantics and Igbo language. She has published Chinua Achebe Things Fall Apart: A compass for Igbo Culture, in Chinua Achebe and the convolution of Immortality (75-84). She is also a PhD student in the department of Linguistics, Igbo and Other Nigerian languages, University of Nigeria, Nsukka.

She is also a PhD student in the department of Linguistics, Igbo and Other Nigerian languages, University of Nigeria, Nsukka.

Chinaza Loveline Ugochukwu hails from Anambra state. She got her B. A (Linguistics) at the department of Linguistics, Igbo and Other Nigerian Languages, University of Nigeria, Nsukka. She specialises in Sociolinguistics. 